NBER WORKING PAPER SERIES

\title{
CEO PAY AND FIRM PERFORMANCE: DYNAMICS, ASYMMETRIES, AND ALTERNATIVE PERFORMANCE MEASURES
}

Paul L. Joskow

Nancy L. Rose

Working Paper No. 4976

\author{
NATIONAL BUREAU OF ECONOMIC RESEARCH \\ 1050 Massachusetts Avenue \\ Cambridge, MA 02138 \\ December 1994
}

We thank Catherine Wolfram for superb research assistance, and the MIT Center for Energy and Environmental Policy Research and the National Science Foundation for financial support. Rose gratefully acknowledges fellowship support from the Center for Advanced Study in the Behavioral Sciences. We appreciate the comments of seminar participants at UCLA. This paper is part of NBER's research program in Industrial Organization. Any opinions expressed are those of the authors and not those of the National Bureau of Economic Research.

(C) 1994 by Paul L. Joskow and Nancy L. Rose. All rights reserved. Short sections of text, not to exceed two paragraphs, may be quoted without explicit permission provided that full credit, including $\odot$ notice, is given to the source. 


\title{
CEO PAY AND FIRM PERFORMANCE: DYNAMICS, ASYMMETRIES, AND \\ ALTERNATIVE PERFORMANCE MEASURES
}

\begin{abstract}
This study explores the dynamic structure of the pay-for-performance relationship in CEO compensation and quantifies the effect of introducing a more complex model of firm financial performance on the estimated performance sensitivity of executive pay. The results suggest that current compensation responds to past performance outcomes, but that the effect decays considerably within two years. This contrasts sharply with models of infinitely persistent performance effects implicitly assumed in much of the empirical compensation literature. We find that both accounting and market performance measures influence compensation and that the salary and bonus component of pay as well as total compensation have become more sensitive to firm financial performance over the past two decades. There is no evidence that boards fail to penalize CEOs for poor financial performance or reward them disproportionately well for good performance. Finally, the data suggest that boards may discount extreme performance outcomes both high and low - relative to performance that lies within some "normal" band in setting compensation.
\end{abstract}

Paul L. Joskow

Department of Economics

MIT

50 Memorial Drive, E52-373A

Cambridge, MA 02142-1347

and NBER
Nancy L. Rose

Sloan School of Management MIT

50 Memorial Drive, E52-434

Cambridge, MA 02142-1347

and NBER 


\section{Introduction}

The relationship between firm performance and executive pay has been one of the most widely studied questions in the executive compensation literature. ${ }^{1} \mathrm{~A}$ substantial theoretical literature develops optimal executive compensation contracts that link pay to variations in firm performance as a means of aligning the incentives of managers (the "agents") with the interests of shareholders (the "principals"). This theoretical literature has spawned numerous empirical tests of the presence, form and strength of the relationship between executive compensation and firm financial performance. The desirability of "incentive pay" based on firm performance has become so widely accepted that it was written into recent reforms in the corporate income tax code intended to reduce or limit overall CEO pay. Effective January 1, 1994, executive compensation in excess of $\$ 1$ million per year is not deductible as an expense for corporate income tax purposes unless it is based on objective measures of firm performance (sec. $162(\mathrm{~m}))^{2}$

As a theoretical matter, the precise form of the optimal compensation contract is complicated (Rosen, 1992). In general, it will depend on such factors as the preferences of managers toward risk, the sensitivity of managerial effort to compensation, and the information on true managerial performance provided by the measures of firm performance that are observable by boards of directors. Empirical analyses of the pay-for-performance relationship in contrast tend to employ quite simple specifications of how firm performance influences compensation. These specifications vary across a number of dimensions, including the choice of stock

\footnotetext{
${ }^{1}$ See Rosen (1992) for an overview of both the theoretical and empirical literature on this subject.

${ }^{2}$ This revision to the tax code was itself a response to political pressures resulting from widely-read popular commentaries that argued that many CEOs are overcompensated and paid lavishly even when their companies are performing poorly. See, e.g., Crystal, 1991.
} 
market or accounting performance measures, the degree to which performance sensitivities are assumed to be constant across all CEOs and firms or are allowed to vary with some set of observable factors, the assumed functional form of the compensation-performance relationship, and the use of absolute returns or returns relative to some reference group of similar firms. There has been little effort to standardize specifications across empirical studies, or even to compare results across alternative specification choices. ${ }^{3}$

This paper has two primary objectives. First, we examine how more complex measures of firm performance affect the estimated pay for performance relationship. In this analysis we allow firm performance to be measured by a vector of indicators that includes both market return and accounting return measures of financial performance, allows the sensitivity of pay to performance to change over time, and allows the performance sensitivity to depend on how good or bad the firm's financial performance has been. We believe that this richer specification of firm financial performance is essential given that traditional measures necessarily are noisy signals of underlying managerial performance. A broader set of measures is likely to provide a better signal of managerial performance than does a single unidimensional performance measure, and appears to accord more closely with institutional descriptions of the compensation process (see Milgrom and Roberts, 1992, chapter 13).

Our second objective is to explore the dynamic structure of the pay-forperformance relationship. A variety of different functional forms has been used in the literature, embodying quite different implicit assumptions about the persistence of firm performance effects on executive pay. At one extreme are specifications that assume

3 Gibbons and Murphy (1990) provide one of the few analyses that report results for different functional forms, but even their study focuses on choosing one form lusing a minimum least squares based criterion), rather than on interpreting the differences in the results. 
no memory in the compensation process. Current compensation is influenced by current performance only; past financial performance has no impact. At the other extreme are specifications that assume complete persistence: current compensation is determined by current financial performance and all previous performance realizations, with all realizations weighted equally. ${ }^{4}$ Few authors have acknowledged the implication of these differing assumptions, and this paper, along with independent work by Boschen and Smith (1994) is among the first to test them explicitly. ${ }^{5}$

Our empirical analysis relies on data for 1009 CEOs in 678 firms over the 1970 through 1990 period. It leads to the following general conclusions:

1. CEO compensation became significantly more sensitive to firm performance during the 1980s compared to the 1970s, even when those portions of executive compensation derived from stock options and related instruments are excluded.

2. CEO compensation is influenced by both accounting profits and shareholder returns. Our results suggest that boards of directors treat each of these performance measures as a useful independent signal of managerial performance. During the 1980s, a given percentage point increase in accounting returns yields three to four times the average overall compensation increase generated by the same percentage

${ }^{4}$ That is, a given return realization has the same effect on current compensation whether it reflects the current return or the return 10 years ago.

5 Since completing our original analysis for this paper, we have discovered a study that independently addresses this topic lour thanks to the Financial Economics Network for its dissemination of working paper abstracts!). Boschen and Smith (1994) use a vector autoregressive approach that relates the level of current compensation (in logs; either salary and bonus or total compensation) to current and past financial performance (measured by stock market rates of return) and lagged compensation, and the level of financial performance to current and past compensation and lagged financial performance. Their analysis uses 3 lags in both compensation and market rates of return. Their estimates, based on data for 16 firms over the 1948-1990 period, yield the same general conclusions as our results. Past performance appears to have a significant influence on current compensation, but the effect is not permanent. Their study also indicates changes in performance sensitivity of pay over the 4 decades spanned by their data, although the relatively small size of their cross section may somewhat limit the generalizations one can draw from this finding. 
point increase in market returns, although this appears to be due at least partially to the smaller variance of accounting returns. For our overall sample, a one standard deviation increase in accounting returns leads to roughly twice the compensation increase of a one standard deviation in market returns. Failing to include both accounting and market return performance measures in the compensation equation substantially underestimates the overall impact of financial performance on CEO pay.

3. Past financial performance, in addition to contemporaneous performance, has an important impact on current CEO compensation. During the 1980s, the contemporaneous compensation effect of an increase in market return is less than forty percent of the cumulative compensation increase, all else equal. For accounting returns, the contemporaneous effect is roughly sixty-five percent of the overall compensation response. The impact is not infinitely persistent, however, as implicitly assumed in many previous studies. Our findings suggest that neither of the functional forms most common in the executive compensation literature accurately captures the temporal structure of the pay-for-performance relationship.

4. The data provide virtually no support for the popular view that boards fail to penalize CEOs for poor performance or reward them disproportionately well for good performance. While much of the increased sensitivity of pay to performance in the 1980s appears due to an increase in the rewards for positive performance, this generally has brought the response of executive pay to good and bad performance into rough symmetry.

5. There is some evidence that boards discount extreme realizations of performance--both high and low-- relative to performance that lies within some "normal" performance band. This could be consistent, for example, with the view that extreme performance realizations are noisy outcomes more likely to be due to events beyond the influence or control of management, or with efforts to limit the extreme variability of compensation in response to managerial risk aversion. 
The paper proceeds as follows. In section II, we discuss the choice of an empirical specification of the pay-for-performance relationship. Section III describes the data and our econometric model of CEO compensation. Results are presented in section IV, followed by a brief conclusion.

\section{Empirical Models of the Pay-for-Performance Relationship}

An extensive empirical literature investigates the sensitivity of top executive pay to variations in firm performance. Rosen (1992) provides an overview of many of these analyses; Sloan (1993) provides additional references to the accounting literature on this topic. We have identified four dimensions along which empirical analyses tend to vary. These are: 1) The choice of performance measure (accounting-based, stock market-based, or both); 2) Whether performance sensitivities are restricted to be the same or are allowed to vary across firms; 3) The functional form of the compensation-return specification; and 4) The use of absolute returns or returns relative to other firms in the same industry or overall market. To the best of our knowledge, the literature is uniform in imposing constant performance coefficients over time ${ }^{6}$ and estimating a constant performance slope over the entire range of the chosen performance measure. We describe below each of these dimensions of the pay-for-performance specification and sketch its implications for our investigation.

1). Stock-market v. accounting performance: In the economics and finance literatures, most studies of the pay-for-performance relationship focus on stock market-based measures of financial performance (e.g., Murphy, 1985; Jensen and Murphy, 1990; Gibbons and Murphy, 1990; Barro and Barro, 1990; and Hubbard and Palia, 1994). In contrast, studies in the accounting literature typically use either

\footnotetext{
${ }^{6}$ See Boschen and Smith (1994) for the one exception of which we are aware.
} 
accounting-based measures of firm performance, or include both accounting and stock market measures of performance in their analysis (e.g., Antle and Smith, 1986; Lambert and Larcker, 1987; and Sloan, 1993). ${ }^{7}$

While the appropriate choice of performance measure is not obvious a priori, it seems reasonable to expect both accounting and market measures of firm financial performance to influence compensation. Boards must confront the task of extracting information about true managerial performance from noisy financial performance realizations. Both accounting and market returns are determined in part by factors beyond the control or influence of the firm's managers. To the extent that they also are influenced by the quality of managerial inputs and actions, they may provide useful information on managerial performance. Given the imperfect correlation between these financial performance measures, the theoretical literature suggests that contracting on both may enhance the firm's ability to filter the signal of true managerial input (e.g., Holmstrom, 1979). Institutional factors support this conclusion, as firms appear in practice to use both measures. Compensation contracts most frequently link bonuses to accounting earnings (Sloan, 1993) while stock-based forms of compensation, particularly options grants, tie realized compensation to stock market returns.

We explore models that include both accounting and market-based measures in the specification of firm performance.

2). Changes in performance sensitivities over time: Most studies of executive compensation estimate a single return coefficient for a panel of firms and CEOs over time. The primary exceptions are: accounting studies, which tend to estimate performance slopes on a firm-by-firm basis (e.g., Lambert and Larcker, 1987 and

${ }^{7}$ Exceptions to this division by field are Kaplan (1994), who includes both market returns and a dummy variable for negative accounting earnings; and Joskow, Rose and Shepard (1993) and Rose and Shepard (1994), discussed below. 
Sloan, 1993, who explore how the relative market and accounting performance sensitivities vary with their signal-to-noise ratios for each firm); Gibbons and Murphy (1992), who find evidence that the performance sensitivity of pay varies over a CEO's career; Schaefer (1993), who develops theoretical and empirical support for an inverse relation between performance sensitivity and firm size (measured by dollar changes in compensation on dollar changes in market value); and Boschen and Smith (1994), who analyze how the pay-for-performance relationship varies over 1948-1990 for their sample of 16 large companies.

In this study, we explore whether the sensitivity of executive pay to firm performance has been constant over time. The rhetoric of corporate proxy statements and business press discussions of CEO compensation strongly suggest that incentive pay has become more visible and widespread over the last 20 years. Some empirical support for this view is provided by the compensation levels equations estimated by Joskow, Rose, and Shepard (hereafter, JRS, 1993), which suggest that performance sensitivities for unregulated industries increased steadily between 1970 and 1990 . To accommodate potential changes in the sensitivity of executive pay to firm performance, we estimate separate performance slopes for the 1970 s and 1980s. ${ }^{8}$

3). Asymmetries in performance sensitivities: We examine a variety of potential asymmetries in the responsiveness of executive pay to variations in firm performance. Of particular interest is the claim that executive pay packages have "more upside than downside elasticity" (Crystal, 1992, p. 98). This argument, which has attracted considerable popular attention, suggests that executive compensation is more sensitive to positive performance realizations than to negative performance realizations. We test for potential asymmetries in performance sensitivities by

\footnotetext{
${ }^{8}$ JRS estimated separate slope coefficients over five-year intervals. While there appears to be some additional variation within decades, the 10 -year splits reported in this paper capture much of the differences over time while preserving some parsimony in the length of the estimated parameter vector.
} 
investigating whether compensation is unusually sensitive to very poor financial performance (measured by accounting losses), whether compensation responds more to performance gains than to performance losses, and whether compensation responds differentially to performance changes that are within some "normal" range as opposed to outside that band.

4). Functional form and the temporal structure of pay-for-performance: This is the dimension on which empirical studies exhibit the least consistency or consensus, even across different studies by the same author. Common specifications correspond to regressions of the log of compensation on the share price (e.g., Murphy, 1985), dollar compensation on the dollar market value of the firm (e.g., Jensen and Murphy, 1990); changes in the log of compensation on the market rate of return (e.g., Gibbons and Murphy, 1990); and the log of compensation on the rate of return (e.g., JRS, 1993). Compensation equations may be estimated in levels or first differences (changes in compensation), in which case both compensation and performance are measured as changes in the described variables. Studies that use both accounting and market-based returns commonly model changes in the log of compensation as a function of the level of market return and the change in the accounting return. ${ }^{9}$

These alternative specifications imply quite different dynamic models of the compensation process. For example, a model of changes in log compensation on the level of return implies complete persistence in the performance component of CEO compensation. ${ }^{10} \mathrm{~A}$ one-time shock to the firm's "normal" return generates a

\footnotetext{
${ }^{9}$ See Lambert and Larcker (1987) and Sloan (1993) for examples. Some of these studies use the dollar change in compensation, rather than the change in the log of compensation, as the dependent variable. The results reported in this paper all use log compensation (or its first difference) rather than the dollar value of compensation, to limit the potentially disproportionate influence of observations with extremely high compensation levels.

10 Models that specify compensation to be a function of market value or share price suggest that superior financial performance prior to the current executive's tenure increase his or her current compensation, all else equal.
} 
permanent change in compensation, even as return recedes to its normal level in subsequent years. Alternatively, a model of changes in log compensation on changes in return implies that the relationship between compensation and performance is contemporaneous only. A one-time shock to return generates higher compensation only in the current period.

Most models that relate log compensation to returns can be nested within a simple dynamic model of the relation between compensation and firm performance over time:

$$
\text { In Compensation } \text { C }_{i t}=\ln \mathrm{C}_{0 \mathrm{it}}+\sum_{\mathrm{s}=0}^{\mathrm{t}} \beta_{\mathrm{s}} \text { Return }_{\mathrm{i}, \mathrm{t}-\mathrm{s}}+\epsilon_{\mathrm{it}}
$$

where $\mathrm{C}_{\text {oit }}$ is the base (non-performance related) compensation for CEO $i$ in year $t$ and RETURN is the market return in each year of CEO $i^{\prime}$ s tenure $(0$ through $t)$. An increase of $x$ percentage points in RETURN in year $(t-s)$ increases compensation in year $t$ by $\beta_{s}$ in this model. The first difference form of this model is:

$$
\begin{aligned}
\operatorname{lnC}_{i t}-\ln C_{i, t-1}= & \left(\operatorname{lnC}_{0 i t}-\operatorname{lnC}_{0 i, t-1}\right)+\beta_{0}\left(\text { Return }_{i t}-\text { Return }_{i, t-1}\right) \\
& +\beta_{1}\left(\text { Return }_{i, t-1}-\text { Return }_{i, t-2}\right)+\ldots \\
& +\beta_{t-1}\left(\text { Return }_{i 1}-\text { Return }_{i 0}\right) \\
& +\beta_{t} \text { Return }_{i 0}+\left(\epsilon_{i t}-\epsilon_{i, t-1}\right)
\end{aligned}
$$

If all the return coefficients are equal $\left(B_{0}=B_{1}=\ldots=B_{t}\right)$, this model collapses to a specification that relates changes in log compensation to the current level of return: 


$$
\left(\ln C_{i t}-\ln C_{i, t-1}\right)=\left(\ln C_{0 i t}-\ln C_{0 i, t-1}\right)+\beta_{0} \operatorname{Return}_{i t}+\left(\epsilon_{i t}-\epsilon_{i, t-1}\right)
$$

In this specification, an increase of $x$ percentage points in RETURN in any year increases the CEO's compensation in that year and every subsequent year by $x ß$ percent. $^{11}$

Alternatively, if current compensation is a function of contemporaneous financial performance only, then $B_{1}=B_{2}=\ldots=B_{t}=0$, and the general model collapses to a specification that relates changes in log compensation to the first difference in return:

$$
\begin{aligned}
&\left(\ln C_{i t}-\ln C_{i, t-1}\right)=\left(\ln C_{0 i t}-\ln C_{0 i, t-1}\right)+\beta_{0}\left(\text { Return }_{i t}-\right.\text { Return } \\
&i, t-i)(4) \\
&+\left(\epsilon_{i t}-\epsilon_{i, t-1}\right)
\end{aligned}
$$

We explicitly test these extreme specifications by nesting them within the more general model of equation (2) and testing whether the restrictions implied by either (3) or (4) are satisfied by the data. Our approach allows us to determine whether the compensation process includes any "memory," in that previous financial performance affects current compensation levels, as well as whether this effect decays over time. There is little reason to think that the compensation-performance relationship must be entirely contemporaneous or perfectly persistent, ${ }^{12}$ even though most studies in the

11 Note that there is a problem of asymmetry in this representation of the notion of persistence. If the market return is 10 percent this year and -9.09 percent next year, so that the net compounded return over the two years is zero, compensation in every subsequent year will be $.91 \beta$ percent higher than it would have been if the return were identically zero in each vear.

${ }^{12}$ See, e.g., Lambert (1983). 
literature implicitly have assumed one of the two extremes. If executive compensation depends on both past and current performance, but the compensation impact of past performance decays over time, we would expect to find that the estimated $\left\{B_{i}\right\}$ are non-zero for some period, but decline as firm performance recedes further into the past. We assess the dynamics of the pay-for-performance relationship with a model that includes current, one- and two-year lags in both accounting and market returns. ${ }^{13}$

4). Absolute v. relative performance measures: A number of studies explore whether executive compensation responds to absolute measures of firm performance or to performance relative to that of some reference group of firms (e.g., Antle and Smith, 1985; Barro and Barro, 1990; Gibbons and Murphy, 1990; Janakiraman, Lambert and Larcker, 1992; and Sloan, 1993). Apart from Gibbons and Murphy, however, most studies conclude that relative performance evaluation (RPE) tends to play a minor role in determining executive compensation. That is, compensation responds primarily to a firm's own return rather than to its return relative to some benchmark group of firms. Moreover, it appears that RPE, if it operates at all, is strongest for quite broad reference groups, corresponding to 1-digit SIC code industries or perhaps the market as a whole. Finally, the slope of the pay-forperformance relationship seems to be quite robust to the inclusion or exclusion of returns for alternative reference groups (see Gibbons and Murphy, 1990). In light of these previous results, and to limit the dimension of the performance parameter vector we estimate, we adopt a specification that implicitly measures return and

\footnotetext{
${ }^{13}$ First-difference models with two lags may be estimated only for observations in which the CEO has four or more years of tenure. We have experimented with longer lag structures, but these lead to substantial loss in data given the average CEO tenure of 7 years in our full dataset. For this reason, we restrict the results reported here to relatively short performance histories. Because the performance impact on current compensation declines considerably over even the two year lags we consider, this restriction does not seem unreasonable.
} 
compensation relative to the overall market (by including individual year effects in the regression model), but do not investigate the RPE hypothesis any further. ${ }^{14}$

\section{Data and Empirical Methodology}

We model CEO compensation as a function of firm scale, firm financial performance, CEO characteristics, and industry and market-wide norms in executive pay. The data used to measure these variables are described below. We next sketch the basic regression model, which is similar to models used by JRS (1993) to investigate compensation differentials across regulated and unregulated industries and by Rose and Shepard (1994) to explore the effects of firm diversification on compensation. We finally summarize our tests of the key restrictions on the performance sensitivity parameters of executive pay that are implicit in this model.

\section{Data}

Our data base is developed from three primary sources. Information on CEO compensation and CEO characteristics were obtained from Forbes' annual CEO compensation survey over 1970-1990. Information on firm characteristics and accounting profitability come from COMPUSTAT, and fiscal year stock market returns are from the Center for Research on Security Prices (CRSP) return files. ${ }^{15}$ To reduce non-comparability across firms we exclude those in industries subject to economic regulation and those in financial services, using COMPUSTAT's primary SIC code

\footnotetext{
${ }^{14}$ We also include aggregated 2-digit SIC industry fixed effects, which implicitly control for industry average performance over the entire sample period (see JRS for a description). The dimension of the performance parameter space $(K)$ for our chosen specification suggests the prudence of suppressing an explicit investigation of RPE parameters, which would increase the parameter vector to $2 \mathrm{~K}$. In our simpler specifications, $K=10$; this increases quickly to $K=20$ or $K=30$ as we relax various restrictions.

${ }^{15}$ See JRS (1993) for a description of the basic dataset.
} 
assignment to determine industry affiliation. ${ }^{16}$ Because some of the specifications that we present include first differences in compensation and up to two-period lags in performance variables, we work with a basic sample of CEO-years for which we observe at least one prior year of compensation and three prior years of performance data. These criteria yield a panel data set of 4697 observations on 1009 CEOs in 678 firms. Descriptive statistics for this sample are reported in Table 1. Variables are described below.

Compensation Measures: We report results for two measures of compensation. The first, SALARY, includes current and deferred salary and bonus. This generally is the least inclusive measure of compensation reported by Forbes, and its definition is relatively consistent over the entire sample period we analyze. ${ }^{17}$ Real SALARY, in 1990 constant dollars, grew at an average annual rate of $4.0 \%$ for our sample, and averaged $\$ 799,000$ overall. Despite this growth, SALARY accounts for a decreasing share of overall compensation over time. Salary and bonus payments averaged $82 \%$ of total compensation reported by Forbes for our sample, and the ratio of salary and bonus to total compensation declined by an average of 1.1 percentage points per year between 1972 and 1990 .

The second measure of compensation, TOTAL, is the most inclusive compensation measure reported by Forbes, although its components vary considerably over time as SEC reporting requirements and Forbes's reporting format change. TOTAL includes salary and bonus, contingent compensation excluded from SALARY, the cash value of company-provided benefits (such as company-paid life insurance, private automobiles, and drivers), and realized net gains from the exercise of stock options, stock appreciation rights, and stock accrual rights. TOTAL compensation in

\footnotetext{
${ }^{16}$ JRS discuss the significant differences in the compensation relationship between CEOs of firms subject to economic regulation and those that are not.

${ }^{17}$ Forbes does not report base salary separately from bonus payments after 1971.
} 
1990 constant dollars averaged $\$ 1.25$ million for our sample, and grew at an average annual rate of $5.9 \%$ between 1972 and 1990 .

While TOTAL is the most inclusive measure of compensation we have, its treatment of stock options, appreciation rights, and accrual rights prevent it from accurately measuring overall current compensation. ${ }^{18}$ This will induce a "lumpiness" in reported TOTAL compensation that may limit its usefulness in our analysis, even though total compensation (correctly measured) is the theoretically appropriate construct on which this analysis should focus.

Firm Scale: The relationship between CEO compensation and firm size is one of the most consistent empirical results in the compensation literature, with most studies reporting a compensation elasticity with respect to firm revenues (SALES) of about . 25 (Rosen, 1992). We have experimented with a variety of scale measures, including SALES, book assets, and employees. The firms in our sample are large on all three dimensions. They average $\$ 5.3$ billion in 1990 constant dollar sales, $\$ 4.3$ billion in constant 1990 dollar assets, and 38,000 employees. Because the estimated pay-for-performance relationship appears to be reasonably robust to alternative definitions of firm scale, we report results only for specifications that use SALES, the dominant measure of firm scale in the compensation literature.

Firm Financial Performance: The basic constructs that we use to measure firm performance are stock market rates of return and accounting rates of return. The market return (MKTROR) is the annual rate of return to common equity shareholders during the firm's reported fiscal year, and is constructed from CRSP return tapes. The

\footnotetext{
${ }^{18}$ As noted in JRS (1993), an ideal measure of total compensation would include the ex ante value of options grants (or similar instruments) in the year they are awarded and the ex post change in the value of previously awarded (as yet unexercised and unexpired) options each year. It seems impossible to construct these exact measures, and difficult to construct even close approximations to them, from 1970 through 1990 proxy statements. SEC reporting requirements in place for 1993 and subsequent years' proxy statements should make these calculations more feasible in the future.
} 
accounting rate of return (ACCROE) is defined as reported earnings excluding extraordinary items divided by total common equity (book value), and is constructed from COMPUSTAT data. ${ }^{19}$ Although the means of these two return measures are roughly comparable, stock market returns exhibit much greater variance: Stock market returns for our sample average $17 \%$, with a standard deviation of $39 \%$. Accounting returns average $14 \%$, with a standard deviation of $10 \%$. The two measures are correlated at the .18 level in our data.

From these basic constructs we define a number of additional performance measures that are used in our analysis of asymmetric performance sensitivities. NEGATIVE EARNINGS is an indicator variable equal to one for observations with negative reported accounting earnings during the period. MEDIAN_ $\triangle M K T R O R$ and MEDIAN_ $\triangle A C C R O E$ are variables that denote the annual median change in market and accounting returns, respectively, for the full JRS dataset of unregulated, nonfinancial companies. We use these variables to separate our sample observations into companies that have close to median performance changes in a given year and those whose performance change is substantially above or below the median. This allows us to test whether performance sensitivities are dampened at the high or low extremes of performance.

CEO Characteristics: The levels equations model log compensation as a function of CEO characteristics as well as the variables described above. These characteristics include the CEO's tenure in the CEO position (TENURE), his/her age at appointment to the CEO position (AGE), an indicator variable for whether the CEO was an appointment from outside the firm as opposed to an internal promotion (OUTSIDE), and an indicator variable for whether the CEO was the founder of the firm (FOUNDER).

${ }^{19}$ This definition poses a problem when a firm's chronic accounting losses drive the book value of its common equity through zero. We define ACCROE to be missing if the book value of equity is negative and therefore exclude these observations from the basic dataset. 
These variables and their empirical effects on compensation are described in considerable detail in JRS (1993). To conserve space, their coefficients are not reported in the tables below. ${ }^{20}$

\section{A regression model of CEO compensation}

The basic econometric specification of the compensation equation follows from our earlier work (JRS), but is expanded to investigate a richer specification of the performance variables that may influence a CEO's compensation. The basic compensation equation is specified as:

$$
\begin{aligned}
\ln \left(\text { CEO COMPENSATION }_{i j \mathrm{k}}\right) & \left.=\beta_{1} \ln \text { (SALES }_{\mathrm{i} t}\right)+\beta_{2}^{\prime} \text { PERFORMANCE }_{\mathrm{ij} t} \\
& +\beta_{3} \text { CEOTEN }_{\mathrm{i} j \mathrm{t}}+\beta_{4} \text { AGE }_{\mathrm{i} i} \\
& +\beta_{5} \text { OUTSIDE }_{\mathrm{i} j}+\beta_{6} \text { FOUNDER }_{\mathrm{i} i} \\
& +a_{\mathrm{k}}+\delta_{\mathrm{t}}+\epsilon_{\mathrm{ijkt}}
\end{aligned}
$$

where $i$ denotes the CEO, $j$ denotes the firm, $k$ denotes the primary industry identification, and $\mathrm{t}$ denotes the year. Industry effects, $a_{k}$, are measured at an aggregated two-digit SIC code level. These incorporate the impact of industry-level variables, including industry-wide compensation norms, on executive pay. Year effects, $\delta_{t}$, accommodate nonlinear (and non-monotonic) economy-wide trends in real CEO compensation over the sample period. The error term, $\varepsilon_{\mathrm{ijkt}}$, may include CEOspecific effects. Any endogeneity between these and the independent variables in the

20 These variables are incidental to our current analysis. Their estimated coefficients are quite stable and consistent with our earlier results. CEO compensation increases very slightly with a CEO's age at appointment and tenure. CEOs appointed from outside are paid more and founders are paid less, other things equal. 
model can be treated by estimating the model in first-differences rather than levels, and we investigate both specifications in the results reported below. ${ }^{21}$

Performance Specification: The influence of firm performance on executive pay is represented in this equation by the $\operatorname{term} \beta_{2}$ 'PERFORMANCE, where PERFORMANCE is a vector of financial performance variables and $\beta_{2}^{\prime}$ is the vector of associated parameters. We begin with a highly restricted model, similar to that estimated in many previous compensation studies, in which RETURN is a single variable, MKTROR, and $\beta_{2}$ is a scalar parameter. We next relax the assumption of a single performance parameter as we introduce progressively more flexibility into the estimated pay-forperformance relationship. We expand the dimension of the RETURN vector to include current accounting returns (ACCROE), relax the restriction on constant performance sensitivities over time, explore the role of memory in the pay-for-performance relationship, and finally test for asymmetries in performance sensitivities.

\section{Empirical Results}

Table 2 presents results from compensation level equations that use $\ln$ (Salary \& Bonus) as the dependent variable. To keep the size of the tables manageable, we suppress all coefficients except those for firm size and the performance measures. Column 1 displays results for the simplest model, which includes current stock market return as the sole performance measure and restricts the performance semi-elasticity to be the same for all observations. The coefficient on market return implies that a 10 percentage point increase in the market return (about one-quarter of the sample standard deviation of MKTROR) increases salary and bonus by roughly $1.2 \%$ (standard error, . $2 \%$ ). This is broadly similar to results from previous empirical studies (see

\footnotetext{
${ }^{21}$ A fixed-effects estimator also would be appropriate, but is not as widely used in this literature as the first-difference model. To enhance the comparability of our results with those of most earlier studies, we therefore choose to use first-differences.
} 
Rosen, 1992). Column 2, which substitutes the accounting rate of return as the single performance measure, implies that a 10 percentage point increase in accounting return (corresponding to one standard deviation increase in this variable) increases salary and bonus by about $7.6 \%(.5 \%)$.

The results in column 3 include both accounting and market returns, and suggest that both measures are important determinants of executive pay. In this specification, the pay sensitivity to a 10 percentage point movement in return is $0.8 \%$ $(0.2 \%)$ for market returns and $6.9 \%(.5 \%)$ for accounting returns. Thus, even when both return measures are included in the regression, the semi-elasticity of pay is an order of magnitude larger for accounting returns than for market returns. This pattern is consistent with results from previous studies that have included accounting rates of return and with the observation that compensation contracts are much more likely to base bonuses on explicit accounting performance targets than on market-based targets (e.g., Lambert and Larcker, 1987). Given the economic and statistical significance of both accounting and market returns in determining CEO pay, we focus our remaining attention on specifications that include both measures.

Columns 4 through 6 repeat the first three specifications, but allow the performance slopes to differ between the 1970 s and 1980 s. The data clearly reject the restriction of constant slopes over time. ${ }^{22}$ In column 6 , which allows both market and accounting return parameters to differ over time, the performance slopes increase by one-third to one-half between the 1970 s and the 1980 s. This suggests that the increasing emphasis on incentive pay over the sample period carries through to salary and bonus decisions and is not solely a function of increased use of stock options in compensation packages.

22 The test of constant performance slopes over the $1970 \mathrm{~s}$ and $1980 \mathrm{~s}$ for the specifications that include both accounting and market return (column $3 \mathrm{~V}$. column 6 of table 2) yields an F-statistic of 3.04 , distributed as $F(2,4697)$. The critical value for $F(2, \infty, .95)$ is 3.00 . 
Finally, column 7 estimates the more general dynamic performance specification, based on equation (1). This column reports results that include current and two lags for each return measure. ${ }^{23}$ The results from this model of compensation level strongly reject both of the simple models of pay-for-performance dynamics: past performance has an influence on current compensation, but that influence is not perfectly persistent over time. ${ }^{24}$

The dynamic pattern of performance effects on compensation differs considerably between accounting and market performance measures. The estimated overall impact of accounting return on pay is roughly constant between the contemporaneous-only (column 6) and general dynamic (column 7) specifications, but including lagged accounting returns shifts about $20 \%$ of the estimated weight to the previous years' return measures. ${ }^{25}$ The results suggest that a 10 percentage point increase in accounting returns during the 1980 s generates an average cumulative increase in salary and bonus equivalent to $7 \%$ of one year's compensation. ${ }^{26}$

In contrast, the estimated impact of market returns on executive pay is substantially higher in the unrestricted dynamic model, relative to the

${ }^{23}$ We chose this cutoff to conserve data and because the effect of past performance on current compensation appears to decay considerably beyond the first two lags. This reflects our view of the trade-off between estimating additional lags in the performance variables and reducing sample size by restricting the analysis to CEOs with increasingly long average tenures.

${ }^{24}$ The F-statistic for the test that the coefficients on all lagged return measures are zero is 5.48 , distributed as $F(8,4641)$. The F-statistic for the test that the coefficients on current and lagged returns are equal (but different for market and accounting returns, and different between the 1970 s and 1980 s), is 5.82 , distributed as $F(8,4641)$. The critical value for $F(8, \infty, .95)$ is 1.94 .

${ }^{25}$ For example, in the 1980 s, the sum of the coefficients in column $7(.707)$ is slightly lower than the point estimate in column 6 (.742), but well within the standard error of the estimates (.055 for column 6).

${ }^{26}$ Because this increase is realized over 3 years, its present discounted value is somewhat less than $7 \%$. 
contemporaneous-only model of column 6 . The effect of current market return on current pay is slightly higher in column 7 than in column 6 (though within one standard error), and the lagged market return terms more than double that impact. In the 1980s, for example, a 10 percentage point increase in market return generates an average $1.1 \%(.2 \%)$ increase in current compensation, $1.0 \%(.2 \%)$ increase in next year's compensation, and $0.4 \%(.2 \%)$ increase in the following year's compensation. The combined effect is equivalent to a one-time increase of roughly $2.5 \%$ in salary and bonus. These results suggest that levels specifications that assume the pay-forperformance relationship is only contemporaneous underestimate the impact of market performance on CEO pay.

We explore the intertemporal structure of the pay-for-performance relationship in further detail in table 3 , using first-difference models of compensation. These regressions model changes in $\ln (\mathrm{SALARY}$ ) as a function of changes in $\ln$ (SALES), year and industry effects, and alternative specifications of the performance measures. To limit the size of the table, we use changes in accounting return in all specifications that include an accounting measure of performance. We vary the specifications to examine both levels of market return and changes in market return.

Columns 1,2 , and 3 in table 3 model changes in In(SALARY) as a function of changes in market returns. These correspond to simple first-difference estimates of the specifications reported in columns 1,2 , and 6 of table 2 . These restricted models, based on equation (3), implicitly assume no "memory" in the compensation process: a one-time shock to return generates a one-time shock to compensation. The estimated coefficients are considerably smaller than those reported in table 2, suggesting that positive correlations between unobserved CEO-specific effects and firm performance may overstate the performance sensitivity of pay in compensation levels equations. 
Columns 4 and 5 of table 3 model changes in $\ln ($ SALARY) as a function of the level of market return. These correspond to the restricted model of equation (4), which assumes that performance effects are perfectly (and infinitely) persistent: a one-time shock to the firm's market return triggers a permanent increase in current and future compensation. These results imply much greater sensitivity of executive pay to market returns than do the column 1-3 results. The 1980 s market return coefficient of $.093(.012)$ in column 5 implies that an additional 10 percentage points in market return generates an increase of $9.3 \%$ in salary and bonus in the current year and in all subsequent years. These estimates are comparable to those reported by Gibbons and Murphy (1990) for a somewhat different Forbes sample and slightly modified, but similar, compensation equations. ${ }^{27}$

The choice of functional form makes a significant difference to the fit of these restricted equations. A minimum least squared errors test would prefer the restricted model of equation (4) to the restrictions imposed by equation (3) (compare the SSR of columns 1 and 4 or of columns 3 and 5). If one is forced to choose between one of these two highly simplified specifications, assuming that performance effects are perfectly persistent appears to better satisfy the data. As in the levels equations, however, this specification is strongly rejected in favor of the more general dynamic model of equations (1) and (2).

Column 6 of table 3 reports results for the general dynamic performance structure. This model corresponds to first-difference estimates of the specification reported in column 7 of table 2 , and is based on the first-difference equation (2).

27 The Gibbons and Murphy sample covers a shorter time period (1974-1986) but larger sample of CEO-years than does ours (due partially to our exclusion of financial sector and regulated firms and the elimination of the first three years of each CEO's tenure due to the data requirements of our lagged return structure tests). Gibbons and Murphy do not include sales and do include various industry return measures as variables in their compensation equations. 
These estimates decisively reject both the restriction that performance effects are contemporaneous only ${ }^{28}$ and the restriction that the performance coefficients are constant over time. ${ }^{29}$ The pattern of coefficients highlights the reasons these restrictions are rejected. Focusing on the 1980s, for market returns the previous year's stock market performance appears to have about the same, or slightly more, impact on current compensation as does current market returns $(.078(.010)$ for current, .095 (.011) for lagged once returns). The impact of previous market performance on current compensation drops quite sharply after one year, however. The coefficient on returns from year $\mathrm{t}-2$ is less than half the magnitude of the returns coefficient for year t-1, at .042 (.009). Accounting return coefficients exhibit a smoother pattern of decay over time, declining about 60 percent each year from the contemporaneous return impact of $.573(.040)$. Nevertheless, assuming that past accounting returns have no impact on current compensation misses about 35 percent of the cumulative three-year compensation response to a shock in accounting returns. Finally, we note that the market return estimates from the general dynamic firstdifference model in column 6 , table 3 , are quite similar to those of the levels model in column 7 of table 2. This may suggest that the differences between these two estimation methods for the contemporaneous-only model are due more to mis-

${ }^{28}$ The F-tests for the restriction that lagged market return coefficients are zero is 22.08 , distributed as $F(4,4647)$; that lagged accounting return coefficients are zero is 7.40 , distributed as $F(4,4647)$; that all lagged performance coefficients are zero is 17.94 , distributed as $F(8,4647)$. The .95 level critical values are: $F(4, \infty)=2.37, F(8, \infty)=1.94$.

29 The F-statistic for the test that current and lagged market return parameters are equal (within decade) is 10.86 , distributed as $F(4,4647)$; that current and lagged accounting parameters are equal (within decade) is 25.54 , distributed as $F(4,4647)$; and that both of these sets of restrictions are satisfied is 21.35 , distributed as $F(8,4647)$. The .95 level critical values are: $F(4, \infty)=2.37, F(8, \infty)=1.94$. 
specification of the pay-for-performance relationship than to correlation between returns and a CEO-specific component of the error term. ${ }^{30}$

For completeness, we report in column 7 of table 3 estimates from a first difference model that uses the level of market return and its lags rather than firstdifferences in market return. This is similar to the model that assumes completely persistent market performance effects in compensation (e.g., column 5 of table 3 ). If this assumption is correct, the coefficients on the lagged market return terms should be zero. ${ }^{31}$ As expected from the results in column 6 , which nest this model as a special case, the data reject this restriction. ${ }^{32}$ For the 1980 s, the previous year's market return has a slightly larger impact on current compensation than does the current year's return (the coefficient of $.023(.011)$ on lagged return is properly interpreted as the incremental effect over the current return coefficient). The market return from two years ago has less than half the impact on current compensation as the current market return, however, as evidenced by its negative point estimate of $-.049(.010)$.

Given the superiority of the general dynamic specification in both the levels and first-difference equations, we focus our attention on variants of this model in the remaining analysis.

30 The coefficients on current and lagged market return for the 1980 s are quite similar across these two tables. The first difference estimates yield slightly lower coefficient estimates for market returns during the 1970s, and slightly higher estimates for lagged accounting returns (though within a standard error). The similarity of results across levels and first-difference estimates provides some incidental support for the consistency of the underlying model.

31 Returning to the general dynamic specification in first differences, equation (2), the coefficient on contemporaneous market return is $\beta_{0}$, the coefficient on the first lag of market return is $\left(B_{1}-\beta_{0}\right)$, and the coefficient on the second lag of market return is $\left(\beta_{2}-B_{1}\right)$. The complete persistence model assumes that $B_{0}=B_{1}=B_{2}=\ldots=\beta_{1}$.

32 The F-statistic for the restriction that the coefficients on the lagged market return terms are zero is 7.12 , distributed as $F(4,4647)$. 
Table 4 replicates the analysis of Tables 2 and 3 using total compensation (TOTAL) rather than salary and bonus as the measure of executive pay. Column 1 reports the simplest performance specification (market return only, with slopes split by decade) for comparability with table 2 and previous studies. Columns 2 and 3 report results from the "full dynamic" specification, estimated in levels (2) and firstdifferences (3). Total compensation is, not surprisingly, more responsive to market performance variations than is salary and bonus, and the sensitivity increased markedly during the 1980 s. As in the salary and bonus results, past performance influences current compensation but the effect decays after the first lag. ${ }^{33}$ In the first difference model of column 3, a 10 point increase in current market return during the 1980 s increases total compensation by $1.3 \%(.2 \%)$ this year, $2.3 \%(.3 \%)$ next year, and $1.1 \%(.2 \%)$ the following year, for a cumulative effect equivalent to a oneyear increase of $4.7 \%$. This is more than twice the cumulative market return effect on salary and bonus (column 6 , table 3 ). ${ }^{34}$ Perhaps more surprising is the stronger sensitivity of total compensation to accounting performance: the cumulative effect of a 10 percentage point increase in accounting returns in this model is $11.7 \%$, about a third larger than the cumulative effect of accounting return increase on salary and bonus (column 6 of table 3).

${ }^{33}$ The estimates in both columns 2 and 3 reject both of the restricted models of the payfor-performance relationship. For the first-difference model, the F-statistic for the test that the relationship is contemporaneous only is 21.00 for market returns, 13.81 for both market and accounting returns, distributed as $F(4,4609)$ and $F(8,4609)$ respectively. The F-statistic for the test that the relationship is perfectly persistent (equal performance slopes over time) is 10.26 for market returns and 8.51 for both market and accounting returns, distributed as $F(4,4609)$ and $F(8,4609)$ respectively.

34 The larger impact of past market returns on total compensation than on salary and bonus is not unexpected, given the construction of TOTAL. TOTAL includes the value of stock options as they are exercised, which will depend heavily on previous years' market returns. 
As our final step in modelling the pay-for-performance relationship, we explore potential asymmetries in the impact of performance on CEO compensation. We consider three types of possible asymmetries. First, is compensation unusually responsive (or non-responsive) to accounting losses? ${ }^{35}$ Second, does compensation respond differently to performance gains than to performance losses? Third, does compensation respond differently to unusually large changes in performance than to changes within some "normal" range?

Table 5 reports results of these tests for salary and bonus; table 6 repeats the analysis for total compensation. Both tables use the first difference specification of In(compensation) with the general dynamic return structure (as in column 7, table 3 , and column 3, table 4). To simplify the exposition, we report coefficients only for the contemporaneous return measures; the patterns of coefficients on the lagged performance terms tend to be similar but noisier.

In column 1 of tables 5 and 6 we modify our basic specification to include a separate control for negative accounting earnings. To test whether accounting losses shift the level of compensation beyond that predicted by the slope coefficient on $\triangle$ accounting return, we estimate these first difference models using the change in an indicator variable that equals one in years with reported accounting losses. ${ }^{36}$

The results suggest that accounting losses reduce compensation beyond their direct effect through the accounting return variable. While the estimate is fairly noisy for the 1970s, accounting losses during the 1980s reduce salary and bonus by about $12 \%(2 \%)$ and total compensation by about $14 \%(4 \%)$, in addition to the proportional

\footnotetext{
${ }^{35} \mathrm{Kaplan}(1994)$ finds evidence that the compensation of his sample of U.S. CEOs declines in years that the firm reports negative pre-tax income.

${ }^{36}$ This differs from Kaplan (1994), who implicitly assumes that negative earnings affect the rate of change in compensation. Applying Kaplan's specification to our data yields negative, but smaller and noisier, coefficient estimates on the negative earnings indicator variable.
} 
compensation decrease implied by the coefficient on accounting return. Moreover, including this variable appears to reduce the coefficient on current accounting returns by one-fifth to one-quarter. This suggests that compensation is somewhat less responsive to positive accounting returns than to accounting losses--an asymmetry apposite to that frequently claimed in the popular press.

We explore whether compensation responds differentially to performance gains and losses in column 2 of tables 5 and 6 . These regressions allow the slope on the changes in return to differ between increases in return ( $\Delta$ return positive) and decreases in return ( $\Delta$ return negative). We find little evidence of economically significant asymmetries in compensation responses during the $1980 \mathrm{~s}$.

The salary and bonus results suggest that the increased sensitivity of pay to performance during the 1980 s resulted largely from increased responsiveness to positive changes in return. The 1980 s point estimates on current changes in market return suggest slightly more sensitivity to positive changes than to negative ones, but the estimates are within two standard errors of each other, and the point estimates for the lagged return measures are almost identical across increases and decreases. For accounting returns, the 1980 s performance sensitivity is independent of whether the change is positive or negative. The data do not reject the hypothesis that the performance sensitivity is the same for increases and decreases in returns during the 1980s. Although this hypothesis can be rejected for the 1970s, the rejection is in the direction of larger compensation responses to decreases in returns. ${ }^{37}$

The results for total compensation in table 6 , column 2 , are consistent with the conclusion of generally symmetric compensation responses to increases and decreases in returns during the 1980 s. The estimated sensitivities of total compensation to

37 The F-test for the restriction that the slopes are the same across increased and decreased returns in the 1980 s is 1.49 , distributed as $F(6,4635)$. The 95 percent critical value for $F(6, \infty)$ is 2.10 . The corresponding test statistic for the 1970 s is 3.30 . 
increases and decreases in returns typically are quite similar, and the data do not come close to rejecting the restriction of identical slopes for all return measures in either the 1970 s or the 1980 s. $^{38}$ Overall, the results in the first two columns of tables 5 and 6 generate little support for the proposition that poor financial performance is disregarded in setting executive compensation.

Finally, we explore whether compensation responds differentially to unusually large changes in performance. The definition of an "unusually large change in performance" is fairly arbitrary. We operationalize it as follows. For each firm-year we compare the change in each return measure to the median change in that return measure across all firms in the JRS dataset. We then divide the observations into three classes: those in which the change in return was "substantially" below the median change, those within a band around the median change, and those "substantially" above the median change. We have experimented with several numerical thresholds for "substantial." The results reported in the paper use thresholds of more than 20 percentage points above or below the median change in market return, and more than 2 percentage points above or below the median change in accounting return. ${ }^{39}$ The distribution of observations using these thresholds is given in table 7. Forty-two percent of the observations fall within the median band for $\Delta$ market return and 53 percent of the observations fall within the median band for $\triangle$ accounting return under these definitions.

38 The F-statistic for the restriction that return slopes are the same for increases and decreases in return is .54 , distributed as $F(12,4597)$. While the failure to reject this hypothesis may arise in part because of the increased noise in the total compensation equation, an inspection of the point estimates suggests patterns quite similar to those for salary and bonus.

${ }^{39}$ The patterns we describe below are fairly consistent across other thresholds we have examined. 
The results are reported in the last columns of tables 5 and 6 . For parsimony and because the data generally do not reject the restriction of common slope coefficients for observations above and below the median band, we report a single coefficient for these observations (denoted as "outside the median band"). ${ }^{40}$ For accounting returns, compensation may be much more responsive to changes within the median band than to changes outside the median band. The accounting return coefficients differ by roughly a factor of two or more for both salary and bonus and total compensation, although the point estimates are sufficiently noisy that the restriction of common slopes across the return range cannot be rejected. This pattern would be consistent with some smoothing by boards of directors when accounting earnings experience unusually large movements from one year to the next. For market returns, the results suggest roughly constant performance sensitivity across the entire range: the point estimates generally are quite close and well within the statistical margin of error from each other. ${ }^{41}$ These results suggest no evidence of compensation smoothing in response to even quite large fluctuations in market returns.

\section{Conclusions}

The results of this study suggest that the pay-for-performance relationship is considerably richer than the models typically incorporated into most previous studies.

\footnotetext{
${ }^{40}$ For salary and bonus, this restriction is rejected only for accounting returns in the 1970 s $(F(3,4604)=4.97)$. For market returns and accounting returns in the 1980 s, the restrictions are not close to rejection $(F(6,4604)=1.01$ for market returns, $F(3,4604)=1.70$ for 1980 s accounting returns). For total compensation, this restriction is not close to rejection for either group of return measures over any decade $(F(6,4585)=.74$ for market returns, $F(6,4585)$ $=.44$ for accounting returns). The 95 percent critical $F$-value for $F(6, \infty)$ is 2.10 , for $F(3, \infty)$ it is 2.60 .

41 The restriction of common slope coefficients across the entire range of changes in market returns is not rejected for either salary and bonus $(F(6,4616)=.47)$ or total compensation $(F(6,4597)=.98)$.
} 
Compensation is sensitive to both accounting and market measures of firm performance, and the sensitivity of executive pay to firm performance has increased considerably during the 1980 s. This increased performance sensitivity is due to more than increased used of stock options in compensation packages, as it carries through to salary and bonus decisions as well.

We find that the dynamic structure of the pay for performance relationship is more complex than implied by the specifications used in earlier compensation analyses. Past financial performance has an effect on current compensation, but the effect appears to decay substantially over two to three years. For market returns, current compensation is influenced as much or more by the previous year's market return (relative to current market returns), but returns more distant than this have a relatively small compensation impact. For accounting returns, the compensation impact decays almost proportionally over time. Our results suggest that failure to model the full dynamic structure of the pay-for-performance relationship may have important consequences for both the magnitude and interpretation of estimated performance sensitivities.

Finally, we find no evidence for the popular view that boards of directors tend to reward good performance and ignore poor performance in setting compensation. Indeed, the strongest evidence of asymmetry in the pay-for-performance relationship is an additional compensation penalty for exceptionally poor accounting performance.

While our estimates of performance sensitivities do not alter the general conclusion that changes in managerial compensation resulting from superior financial performance of the firm are small in comparison to changes in total shareholder wealth, the compensation effects are nonetheless economically important. During the 1980s, a CEO who increased his or her firm's market and accounting returns by onehalf standard deviation over the means in our sample would have generated average compensation increases over the next three years equivalent to roughly $9 \%$ of current 
30

salary and bonus and $15 \%$ of current total compensation. At the sample mean of 1.25 million in total 1990 dollar compensation, this increase would correspond to an additional $\$ 193,000 .^{42}$

42 The lag structure in our model implies that this sum would be earned over a three-year period, so the present discounted value in terms of current compensation is slightly lower. 
References

Antle, Rick and Abbie Smith. "An Empirical Investigation of the Relative Performance Evaluation of Corporate Executives." Journal of Accounting Research. 24 Spring 1986): 1-39.

Barro, Jason R. and Robert J. Barro. "Pay, Performance, and Turnover of Bank CEOs," Journal of Labor Economics. 8 (1990): 448-481.

Boschen, John F. and Kimberly J. Smith. "You Can Pay Me Now and You Can Pay Me Later: The Dynamic Response of Executive Compensation to Firm Performance." College of William and Mary: mimeo, May 1994.

Crystal, Graef S. In Search of Excess. New York: W.W. Norton. 1992.

Gibbons, Robert and Kevin J. Murphy. "Relative Performance Evaluation for Chief Executive Officers." Industrial and Labor Relations Review. 43 (Special Issue, February 1990): 30S - 51S.

Gibbons, Robert and Kevin J. Murphy. "Optimal Incentive Contracts in the Presence of Career Concerns: Theory and Evidence." Journal of Political Economy 100 (1992): 468-505.

Holmstrom, Bengt. "Moral Hazard and Observability." RAND Journal of Economics 10 (Spring 1979): 74-91.

Hubbard, R. Glenn and Darius Palia. "Executive Pay and Performance: Evidence from the Banking Industry." NBER Working Paper No. 4704, April 1994.

Janakiraman, Surya N., Richard A. Lambert, and David F. Larcker. "An Empirical Investigation of the Relative Performance Evaluation Hypothesis." Journal of Accounting Research 30 (Spring 1992): 53-69.

Jensen, Michael C. and Kevin J. Murphy. "Performance Pay and Top-Management Incentives." Journal of Political Economy. 98 (April 1990): 225-264.

Joskow, Paul, Nancy Rose, and Andrea Shepard. "Regulatory Constraints on CEO Compensation." Brookings Papers on Economic Activity - Microeconomics 1993. Microeconomics I(1993): 1-58, 70-72.

Kaplan, Steven N. "Top Executive Rewards and Firm Performance: A Comparison of Japan and the U.S." Journal of Political Economy 102 (June 1994): 510-546. 
Lambert, Richard A. "Long-term Contracts and Moral Hazard." Bell Journal of Economics 14 (Autumn 1983): 441-452.

Lambert, Richard A. "The Use of Accounting and Security Price Measures of Performance in Managerial Compensation Contracts: A Discussion." Journal of Accounting and Economics 16 (January/April/July 1993): 101-123.

Lambert, Richard A. and David F. Larcker. "An Analysis of the Use of Accounting and Market Measures of Performance in Executive Compensation Contracts." Journal of Accounting Research 25 suppl. (1987): 85-125.

Milgrom, Paul R. and John Roberts. Economics, Organizations, and Management. Englewood Cliffs, N.J.: Prentice-Hall, Inc. 1992.

Murphy, Kevin J. "Corporate Performance and Managerial Remuneration: An Empirical Analysis." Journal of Accounting and Economics. 7 (April 1985): 11 42.

O'Reilly, Charles A. III, Brian G. Main, and Graef S. Crystal. "CEO Compensation as Tournament and Social Comparison: A Tale of Two Theories." Administrative Science Quarterly, 33 (1988): 257-274.

Rose, Nancy L. and Andrea Shepard. "Firm Diversification and CEO Compensation: Managerial Ability or Executive Entrenchment?" NBER Working Paper, April 1994.

Rosen, Sherwin. "Contracts and the Market for Executives." In Lars Wernin and Hans Wijkander, eds., Contract Economics. Oxford: Basil Blackwell. 1992.

Schaefer, Scott. "The Dependence of CEO Pay-Performance Sensitivity on the Value of the Firm." Mimeo, Graduate School of Business, Stanford University. January 1993.

Sloan, Richard G. "Accounting Earnings and Top Executive Compensation." Journal of Accounting and Economics 16 (January/April/July 1993): 55-100. 
Table 1: Descriptive Statistics of Performance Sample (4697 CEO-years)

\begin{tabular}{|c|c|c|c|c|}
\hline Variable & Mean & $\begin{array}{l}\text { Standard } \\
\text { Deviation }\end{array}$ & Minimum & Maximum \\
\hline $\begin{array}{l}\text { Salary \& Bonus, } \\
\text { thousands of } 1990 \\
\text { dollars }\end{array}$ & 799.17 & 580.05 & 93.37 & 15207.36 \\
\hline $\begin{array}{l}\text { Total Comp., thousands } \\
\text { of } 1990 \text { dollars }\end{array}$ & 1251.41 & 2184.58 & 132.83 & 67780.39 \\
\hline $\begin{array}{l}\text { Sales, millions of } 1990 \\
\text { dollars }\end{array}$ & 5332.90 & 10496.23 & 22.24 & 158263.50 \\
\hline $\begin{array}{l}\text { Book Assets, millions of } \\
1990 \text { dollars }\end{array}$ & 4288.14 & 9581.64 & 26.00 & 180432.00 \\
\hline Employees, thousands & 38.04 & 59.14 & 0.07 & 876.80 \\
\hline $\begin{array}{l}\text { Stock Market Rate of } \\
\text { Return }\end{array}$ & 0.17 & 0.39 & -0.74 & 6.13 \\
\hline Median $\Delta$ Market Return & -.009 & .247 & -.358 & .641 \\
\hline $\begin{array}{l}\text { Accounting Rate of } \\
\text { Return on Book Equity }\end{array}$ & 0.141 & 0.103 & -1.193 & 1.440 \\
\hline $\begin{array}{l}\text { Median } \Delta \text { Accounting } \\
\text { Return }\end{array}$ & .001 & .010 & -.106 & .103 \\
\hline $\begin{array}{l}\text { Negative Earnings } \\
\text { Dummy }\end{array}$ & .037 & & & \\
\hline Tenure as CEO & 11.72 & 7.91 & 40. & 60. \\
\hline Age at appointment & 47.15 & 8.09 & 19. & 70. \\
\hline Outside Hire & 0.170 & & & \\
\hline pre-1970s & 0.083 & & & \\
\hline during 1970s & 0.071 & & & \\
\hline during 1980 s & 0.017 & & & \\
\hline Company Founder & 0.108 & & & \\
\hline Number of Firms & 678 & & & \\
\hline Number of CEOs & 1009 & & & \\
\hline
\end{tabular}


Table 2: Determinants of In (Salary \& Bonus)

$(N=4697)$

\begin{tabular}{|c|c|c|c|c|c|c|c|}
\hline Variable & (1) & (2) & (3) & (4) & (5) & (6) & (7) \\
\hline In(Sales) & $\begin{array}{r}.253 \\
(.006) \\
\end{array}$ & $\begin{array}{l}.255 \\
(.006) \\
\end{array}$ & $\begin{array}{l}.256 \\
(.006)\end{array}$ & $\begin{array}{l}.254 \\
(.006) \\
\end{array}$ & $\begin{array}{l}.254 \\
(.007) \\
\end{array}$ & $\begin{array}{l}.255 \\
(.006)\end{array}$ & $\begin{array}{l}.258 \\
(.006)\end{array}$ \\
\hline $\begin{array}{l}\text { Market Return, } \\
\text { 1970s }\end{array}$ & \multirow{2}{*}{$\begin{array}{l}.122 \\
(.015)\end{array}$} & & \multirow{2}{*}{$\begin{array}{l}.077 \\
(.015)\end{array}$} & $\begin{array}{l}.092 \\
(.022)\end{array}$ & & $\begin{array}{l}.068 \\
(.023)\end{array}$ & $\begin{array}{l}.074 \\
(.024)\end{array}$ \\
\hline $\begin{array}{l}\text { Market Return, } \\
1980 \text { s }\end{array}$ & & & & $\begin{array}{l}.146 \\
(.020)\end{array}$ & & $\begin{array}{l}.090 \\
(.020)\end{array}$ & $\begin{array}{l}.107 \\
(.021)\end{array}$ \\
\hline $\begin{array}{l}\text { Accounting Return, } \\
1970 \text { s }\end{array}$ & & \multirow{2}{*}{$\begin{array}{l}.755 \\
(.052)\end{array}$} & \multirow{2}{*}{$\begin{array}{l}.694 \\
(.053)\end{array}$} & & $\begin{array}{l}.560 \\
(.114)\end{array}$ & $\begin{array}{l}.471 \\
(.118)\end{array}$ & $\begin{array}{l}.371 \\
(.151)\end{array}$ \\
\hline $\begin{array}{l}\text { Accounting Return, } \\
1980 \text { s }\end{array}$ & & & & & $\begin{array}{l}.803 \\
(.057) \\
\end{array}$ & $\begin{array}{l}.745 \\
(.059)\end{array}$ & $\begin{array}{l}.570 \\
(.073)\end{array}$ \\
\hline $\begin{array}{l}\text { Market Return, t-1, } \\
1970 \text { s }\end{array}$ & & & & & & & $\begin{array}{l}.053 \\
(.024)\end{array}$ \\
\hline $\begin{array}{l}\text { Market Return, } t-1 \text {, } \\
1980 \text { s }\end{array}$ & & & & & & & $\begin{array}{l}.096 \\
(.019)\end{array}$ \\
\hline $\begin{array}{l}\text { Market Return, t-2, } \\
1970 \text { s }\end{array}$ & & & & & & & $\begin{array}{l}.018 \\
(.023)\end{array}$ \\
\hline $\begin{array}{l}\text { Market Return, t-2, } \\
1980 \text { s }\end{array}$ & & & & & & & $\begin{array}{l}.042 \\
(.018) \\
\end{array}$ \\
\hline $\begin{array}{l}\text { Accounting Return, } \\
t-1,1970 \text { s }\end{array}$ & & & & & & & $\begin{array}{l}.081 \\
(.175)\end{array}$ \\
\hline $\begin{array}{l}\text { Accounting Returns, } \\
t-1,1980 \text { s }\end{array}$ & & & & & & & $\begin{array}{l}.119 \\
(.084)\end{array}$ \\
\hline $\begin{array}{l}\text { Accounting Returns, } \\
t-2,1970 \text { s }\end{array}$ & & & & & & & $\begin{array}{l}-.040 \\
(.166)\end{array}$ \\
\hline $\begin{array}{l}\text { Accounting Returns, } \\
\mathrm{t}-2,1980 \mathrm{~s}\end{array}$ & & & & & & & $\begin{array}{l}.027 \\
(.080) \\
\end{array}$ \\
\hline Adjusted $R^{2}$ & .472 & .488 & .491 & .472 & .488 & .491 & .496 \\
\hline SSR & 585.68 & 567.92 & 564.76 & 585.29 & 567.47 & 564.03 & 558.75 \\
\hline
\end{tabular}

Standard errors are in parentheses.

All regressions include controls for CEO characteristics, year effects, and industry fixed effects. 
Table 3: Determinants of $\Delta \ln$ (Salary \& Bonus)

$(N=4697)$

\begin{tabular}{|c|c|c|c|c|c|c|c|}
\hline Market Return: & $\begin{array}{c}(1) \\
\Delta \text { level }\end{array}$ & $\begin{array}{l}(2) \\
-- \\
\end{array}$ & $\begin{array}{c}\text { (3) } \\
\text { Dlevel }\end{array}$ & $\begin{array}{l}\text { (4) } \\
\text { level }\end{array}$ & $\begin{array}{c}\text { (5) } \\
\text { level }\end{array}$ & $\begin{array}{c}(6) \\
\Delta \text { level }\end{array}$ & $\begin{array}{l}\text { (7) } \\
\text { level }\end{array}$ \\
\hline In(Sales) & $\begin{array}{c}.261 \\
(.023)\end{array}$ & $\begin{array}{l}.189 \\
(.023)\end{array}$ & $\begin{array}{l}.197 \\
(.023)\end{array}$ & $\begin{array}{l}.212 \\
(.023)\end{array}$ & $\begin{array}{l}.162 \\
(.023)\end{array}$ & $\begin{array}{l}.170 \\
(.023)\end{array}$ & $\begin{array}{l}.156 \\
(.023)\end{array}$ \\
\hline $\begin{array}{l}\text { Market Return, } \\
1970 \text { s }\end{array}$ & \multirow{2}{*}{$\begin{array}{l}.035 \\
(.006)\end{array}$} & & $\begin{array}{l}.025 \\
(.010)\end{array}$ & \multirow{2}{*}{$\begin{array}{l}.097 \\
(.009)\end{array}$} & $\begin{array}{l}.056 \\
(.013)\end{array}$ & $\begin{array}{l}.040 \\
(.011)\end{array}$ & $\begin{array}{l}.051 \\
(.014)\end{array}$ \\
\hline $\begin{array}{l}\text { Market Return, } \\
\text { 1980s }\end{array}$ & & & $\begin{array}{l}.020 \\
(.008)\end{array}$ & & $\begin{array}{c}.093 \\
(.010)\end{array}$ & $\begin{array}{l}.078 \\
(.010\rangle\end{array}$ & $\begin{array}{l}.082 \\
(.012)\end{array}$ \\
\hline $\begin{array}{l}\Delta \text { Accounting } \\
\text { Return, 1970s }\end{array}$ & & \multirow{2}{*}{$\begin{array}{l}.518 \\
(.034)\end{array}$} & $\begin{array}{l}.358 \\
(.076)\end{array}$ & & $\begin{array}{l}.313 \\
(.078)\end{array}$ & $\begin{array}{l}.385 \\
(.082)\end{array}$ & $\begin{array}{l}.369 \\
(.084)\end{array}$ \\
\hline $\begin{array}{l}\Delta \text { Accounting } \\
\text { Return, 1980s }\end{array}$ & & & $\begin{array}{l}.532 \\
(.038)\end{array}$ & & $\begin{array}{r}.497 \\
(.038) \\
\end{array}$ & $\begin{array}{r}.573 \\
(.041) \\
\end{array}$ & $\begin{array}{l}.584 \\
(.042)\end{array}$ \\
\hline $\begin{array}{l}\text { Market Return, } t-1 \text {, } \\
1970 \text { s }\end{array}$ & & & & & & $\begin{array}{l}.028 \\
(.012)\end{array}$ & $\begin{array}{l}-.0003 \\
(.014)\end{array}$ \\
\hline $\begin{array}{l}\text { Market Return, } t-1 \text {, } \\
\text { 1980s }\end{array}$ & & & & & & $\begin{array}{l}.095 \\
(.011)\end{array}$ & $\begin{array}{l}.023 \\
(.011)\end{array}$ \\
\hline $\begin{array}{l}\text { Market Return, } t-2 \text {, } \\
1970 \text { s }\end{array}$ & & & & & & $\begin{array}{l}.009 \\
(.008)\end{array}$ & $\begin{array}{l}-.008 \\
(.013)\end{array}$ \\
\hline $\begin{array}{l}\text { Market Return, t-2, } \\
1980 \mathrm{~s}\end{array}$ & & & & & & $\begin{array}{l}.042 \\
(.009)\end{array}$ & $\begin{array}{l}-.049 \\
(.010) \\
\end{array}$ \\
\hline $\begin{array}{l}\triangle \text { Accounting } \\
\text { Return, } t-1,1970 \text { s }\end{array}$ & & & & & & $\begin{array}{l}.178 \\
(.087)\end{array}$ & $\begin{array}{l}.147 \\
(.090)\end{array}$ \\
\hline $\begin{array}{l}\Delta \text { Accounting } \\
\text { Returns, } t-1,1980 \text { s }\end{array}$ & & & & & & $\begin{array}{l}.222 \\
(.045)\end{array}$ & $\begin{array}{l}.229 \\
(.046)\end{array}$ \\
\hline $\begin{array}{l}\Delta \text { Accounting } \\
\text { Returns, } \mathrm{t}-2,1970 \text { s }\end{array}$ & & & & & & $\begin{array}{l}.127 \\
(.087)\end{array}$ & $\begin{array}{l}.098 \\
(.090)\end{array}$ \\
\hline $\begin{array}{l}\Delta \text { Accounting } \\
\text { Returns, } t-2,1980 \text { s }\end{array}$ & & & & & & $\begin{array}{r}.082 \\
(.043) \\
\end{array}$ & $\begin{array}{r}.089 \\
(.044) \\
\end{array}$ \\
\hline Adjusted $R^{2}$ & .073 & .112 & .115 & .091 & .127 & .141 & .130 \\
\hline SSR & 195.75 & 187.70 & 187.04 & 192.10 & 184.38 & 181.44 & 181.90 \\
\hline
\end{tabular}

Standard errors are in parentheses.

All regressions include year and industry fixed effects.

Market returns are in levels or differences as specified in the column header. 
Table 4: Determinants of in (Total Compensation)

\begin{tabular}{|c|c|c|c|}
\hline Dependent Variable & \multicolumn{2}{|c|}{ In(Total Compensation) } & $\Delta \ln$ (Total Comp.) \\
\hline Market Return: & level & level & $\Delta$ level \\
\hline $\ln ($ Sales) & $\begin{array}{l}.282 \\
(.009)\end{array}$ & $\begin{array}{l}.295 \\
(.009)\end{array}$ & $\begin{array}{l}.245 \\
(.054)\end{array}$ \\
\hline $\begin{array}{l}\text { Market Return: } \\
1970 \text { s }\end{array}$ & $\begin{array}{l}.157 \\
(.034)\end{array}$ & $\begin{array}{l}.122 \\
(.036)\end{array}$ & $\begin{array}{l}.049 \\
(.027)\end{array}$ \\
\hline $\begin{array}{l}\text { Market Return, } \\
\text { 1980s }\end{array}$ & $\begin{array}{l}.232 \\
(.030)\end{array}$ & $\begin{array}{l}.186 \\
(.030)\end{array}$ & $\begin{array}{l}.133 \\
(.023)\end{array}$ \\
\hline $\begin{array}{l}\text { Accounting Return, } \\
1970 \text { s }\end{array}$ & & $\begin{array}{l}.790 \\
(.203)\end{array}$ & $\begin{array}{l}.725 \\
(.195)\end{array}$ \\
\hline $\begin{array}{l}\text { Accounting Return, } \\
1980 \text { s }\end{array}$ & & $\begin{array}{l}.794 \\
(.107)\end{array}$ & $\begin{array}{l}.682 \\
(.098)\end{array}$ \\
\hline $\begin{array}{l}\text { Market Return, } t-1, \\
1970 \text { s }\end{array}$ & & $\begin{array}{l}.084 \\
(.035)\end{array}$ & $\begin{array}{l}.022 \\
(.029)\end{array}$ \\
\hline $\begin{array}{l}\text { Market Return, } t-1 \text {, } \\
\text { 1980s }\end{array}$ & & $\begin{array}{l}.255 \\
(.027)\end{array}$ & $\begin{array}{l}.230 \\
(.025)\end{array}$ \\
\hline $\begin{array}{l}\text { Market Return, t-2, } \\
1970 \text { s }\end{array}$ & & $\begin{array}{l}.053 \\
(.034)\end{array}$ & $\begin{array}{l}.006 \\
(.018)\end{array}$ \\
\hline $\begin{array}{l}\text { Market Return, t-2, } \\
\text { 1980s }\end{array}$ & & $\begin{array}{l}.136 \\
(.027)\end{array}$ & $\begin{array}{l}.114 \\
(.022)\end{array}$ \\
\hline $\begin{array}{l}\text { Accounting Return, } \\
\mathrm{t}-1,1970 \mathrm{~s}\end{array}$ & & $\begin{array}{l}.138 \\
(.258)\end{array}$ & $\begin{array}{l}.482 \\
(.209)\end{array}$ \\
\hline $\begin{array}{l}\text { Accounting Returns, } \\
t-1,1980 \text { s }\end{array}$ & & $\begin{array}{l}.187 \\
(.123)\end{array}$ & $\begin{array}{l}.262 \\
\{.107\}\end{array}$ \\
\hline $\begin{array}{l}\text { Accounting Returns, } \\
t-2,1970 \text { s }\end{array}$ & & $\begin{array}{l}. .015 \\
(.245)\end{array}$ & $\begin{array}{l}.122 \\
(.214)\end{array}$ \\
\hline $\begin{array}{l}\text { Accounting Returns, } \\
\mathrm{t}-2,1980 \mathrm{~s}\end{array}$ & & $\begin{array}{l}.231 \\
(.117)\end{array}$ & $\begin{array}{l}.227 \\
(.103)\end{array}$ \\
\hline Adjusted $R^{2}$ & .411 & .456 & .075 \\
\hline SSR & 1295.48 & 1196.22 & 1021.28 \\
\hline $\begin{array}{l}\text { Number of } \\
\text { Observations }\end{array}$ & 4677 & 4677 & 4657 \\
\hline
\end{tabular}

Standard errors are in parentheses. Levels regressions include controls for CEO characteristics, year effects, and industry fixed effects. Change regressions are specified as first difference equations and include controls for year and industry fixed effects. Market returns may or may not be differenced, as specified in the column header under the change regressions. 
Table 5: Asymmetries in Pay-for-Performance, $\Delta \ln ($ Salary \& Bonus)

\begin{tabular}{|c|c|c|c|c|c|}
\hline \multirow[b]{2}{*}{$\begin{array}{l}\Delta \text { Return coefficient } \\
\text { differs by: }\end{array}$} & \multirow{2}{*}{$\begin{array}{c}\text { (1) } \\
\text { Single } \\
\text { coefficient }\end{array}$} & \multicolumn{2}{|c|}{ (2) } & \multicolumn{2}{|c|}{ (3) } \\
\hline & & $\begin{array}{l}\text { Negative } \\
\Delta \text { return }\end{array}$ & $\begin{array}{l}\text { Positive } \\
\text { Areturn }\end{array}$ & $\begin{array}{l}\text { Inside } \\
\text { median } \\
\text { band }\end{array}$ & $\begin{array}{c}\text { Outside } \\
\text { median } \\
\text { band }\end{array}$ \\
\hline $\begin{array}{l}\Delta \text { Market return, } \\
1970 \text { s }\end{array}$ & $\begin{array}{l}.041 \\
(.011)\end{array}$ & $\begin{array}{l}.062 \\
(.021)\end{array}$ & $\begin{array}{l}.047 \\
(.015)\end{array}$ & $\begin{array}{l}.019 \\
(.030)\end{array}$ & $\begin{array}{l}.035 \\
(.011)\end{array}$ \\
\hline $\begin{array}{l}\Delta \text { Market return, } \\
1980 \text { s }\end{array}$ & $\begin{array}{l}.079 \\
(.009)\end{array}$ & $\begin{array}{l}.066 \\
(.016)\end{array}$ & $\begin{array}{l}.096 \\
(.015)\end{array}$ & $\begin{array}{l}.101 \\
(.033)\end{array}$ & $\begin{array}{l}.077 \\
(.010)\end{array}$ \\
\hline $\begin{array}{l}\triangle A c c o u n t i n g ~ r e t u r n, \\
1970 \text { s }\end{array}$ & $\begin{array}{l}.327 \\
(.091)\end{array}$ & $\begin{array}{l}.790 \\
(.144)\end{array}$ & $\begin{array}{l}.063 \\
(.118)\end{array}$ & $\begin{array}{l}1.464 \\
(.534)\end{array}$ & $\begin{array}{l}.379 \\
(.082)\end{array}$ \\
\hline $\begin{array}{l}\triangle \text { Accounting return, } \\
1980 \text { s }\end{array}$ & $\begin{array}{l}.423 \\
(.047)\end{array}$ & $\begin{array}{l}.575 \\
(.056)\end{array}$ & $\begin{array}{l}.556 \\
(.073)\end{array}$ & $\begin{array}{l}1.311 \\
(.440)\end{array}$ & $\begin{array}{l}.572 \\
(.041)\end{array}$ \\
\hline $\begin{array}{l}\Delta \text { Negative Earnings } \\
\text { dummy, } 1970 \text { s }\end{array}$ & $\begin{array}{l}-.052 \\
1.0351\end{array}$ & & & & \\
\hline $\begin{array}{l}\Delta \text { Negative Earnings } \\
\text { dummy, } 1980 \mathrm{~s}\end{array}$ & $\begin{array}{l}-.121 \\
(.018)\end{array}$ & & & & \\
\hline Adjusted $R^{2}$ & .150 & & & & \\
\hline SSR & 179.64 & & & & \\
\hline $\begin{array}{l}\text { Number of } \\
\text { Observations }\end{array}$ & 4697 & & & & \\
\hline
\end{tabular}

Standard errors are in parentheses. All regressions include additional lagged first differences in returns, first differences in sales, and year and industry fixed effects. See text for additional description of this table. 
Table 6: Asymmetries in Pay-for-Performance, Din (Total Compensation)

\begin{tabular}{|c|c|c|c|c|c|}
\hline \multirow[b]{2}{*}{$\begin{array}{l}\Delta \text { Return coefficient } \\
\text { differs by: }\end{array}$} & \multirow{2}{*}{$\begin{array}{c}(1) \\
\text { Single } \\
\text { Coefficient }\end{array}$} & \multicolumn{2}{|c|}{ (2) } & \multicolumn{2}{|c|}{ (3) } \\
\hline & & $\begin{array}{l}\text { Negative } \\
\Delta \text { return }\end{array}$ & $\begin{array}{l}\text { Positive } \\
\Delta \text { return }\end{array}$ & $\begin{array}{l}\text { Inside } \\
\text { median } \\
\text { band }\end{array}$ & $\begin{array}{c}\text { Outside } \\
\text { median } \\
\text { band }\end{array}$ \\
\hline $\begin{array}{l}\Delta \text { Market return, } \\
1970 \text { s }\end{array}$ & $\begin{array}{l}.048 \\
(.027)\end{array}$ & $\begin{array}{l}.014 \\
(.052)\end{array}$ & $\begin{array}{l}.089 \\
(.037)\end{array}$ & $\begin{array}{l}-.005 \\
(.073)\end{array}$ & $\begin{array}{l}.049 \\
(.027)\end{array}$ \\
\hline $\begin{array}{l}\Delta \text { Market return, } \\
1980 \text { s }\end{array}$ & $\begin{array}{l}.134 \\
(.023)\end{array}$ & $\begin{array}{l}.165 \\
(.038)\end{array}$ & $\begin{array}{l}.113 \\
(.035)\end{array}$ & $\begin{array}{l}.143 \\
(.078)\end{array}$ & $\begin{array}{l}.133 \\
(.023)\end{array}$ \\
\hline $\begin{array}{l}\triangle A c c o u n t i n g ~ r e t u r n, \\
1970 \text { s }\end{array}$ & $\begin{array}{l}.754 \\
(.220)\end{array}$ & $\begin{array}{l}.998 \\
(.347)\end{array}$ & $\begin{array}{l}.543 \\
(.283)\end{array}$ & $\begin{array}{c}1.381 \\
(1.283)\end{array}$ & $\begin{array}{l}.715 \\
(.196)\end{array}$ \\
\hline $\begin{array}{l}\triangle A c c o u n t i n g ~ r e t u r n, \\
1980 \text { s }\end{array}$ & $\begin{array}{l}.511 \\
(.112)\end{array}$ & $\begin{array}{l}.684 \\
(.135)\end{array}$ & $\begin{array}{l}.661 \\
(.174)\end{array}$ & $\begin{array}{c}1.421 \\
(1.050)\end{array}$ & $\begin{array}{l}.676 \\
(.099)\end{array}$ \\
\hline $\begin{array}{l}\Delta \text { Negative Earnings } \\
\text { dummy, } 1970 \text { s }\end{array}$ & $\begin{array}{l}.019 \\
(.085)\end{array}$ & & & & \\
\hline $\begin{array}{l}\Delta \text { Negative Earnings } \\
\text { dummy, } 1980 \mathrm{~s}\end{array}$ & $\begin{array}{l}-.139 \\
(.044)\end{array}$ & & & & \\
\hline $\begin{array}{l}\text { Adjusted } R^{2} \\
\text { SSR } \\
N\end{array}$ & $\begin{array}{c}.077 \\
1019.00 \\
4657\end{array}$ & $\begin{array}{r}.0 \\
101 \\
46\end{array}$ & & & \\
\hline
\end{tabular}

Standard errors are in parentheses.

All regressions include additional lagged first differences in returns, first differences in sales, and year and industry fixed effects.

See text for additional description of this table. 
Table 7: Distribution of Observations Below, Within, and Above Median Band of $\Delta$ Return

\begin{tabular}{|c|c|c|}
\hline Category & Mean $\Delta$ return & $\begin{array}{l}\text { Number of } \\
\text { observations }\end{array}$ \\
\hline \multicolumn{3}{|l|}{ Market Returns: } \\
\hline $\begin{array}{l}\Delta \text { Market return more than } .20 \\
\text { below median } \Delta \text { mkt return }\end{array}$ & -0.538 & 1435 \\
\hline $\begin{array}{l}\Delta \text { Market return within } .20 \text { of } \\
\text { median } \Delta \text { mkt return }\end{array}$ & -.017 & 1981 \\
\hline $\begin{array}{l}\Delta \text { Market return more than } .20 \\
\text { above median } \Delta \text { mkt return }\end{array}$ & 0.499 & 1281 \\
\hline \multicolumn{3}{|l|}{ Accounting returns: } \\
\hline $\begin{array}{l}\Delta \text { Accounting return more than } \\
.02 \text { below median } \Delta \text { acc return }\end{array}$ & -0.082 & 1181 \\
\hline $\begin{array}{l}\Delta \text { Accounting return within } .02 \\
\text { of median } \Delta \text { acc return }\end{array}$ & 0.002 & 2460 \\
\hline $\begin{array}{l}\Delta \text { Accounting return more than } \\
.02 \text { above median } \Delta \text { acc return }\end{array}$ & 0.072 & 1056 \\
\hline
\end{tabular}

The median $\Delta$ return is defined for each year over the full set of firms in the JRS dataset. 